\title{
Randomized, double-blind, placebo-controlled, linear dose, crossover study to evaluate the efficacy and safety of a green coffee bean extract in overweight subjects [Retraction]
}

\author{
Vinson JA, Burnham BR, Nagendran MV. Diabetes, \\ Metabolic Syndrome and Obesity: Targets and Therapy. \\ 2012;5:21-27. \\ The sponsors of the study cannot assure the validity of the \\ data so we, Joe Vinson and Bryan Burnham, are retracting \\ the paper.
}

\section{Publish your work in this journal}

Diabetes, Metabolic Syndrome and Obesity: Targets and Therapy is an international, peer-reviewed open-access journal committed to the rapid publication of the latest laboratory and clinical findings in the fields of diabetes, metabolic syndrome and obesity research Original research, review, case reports, hypothesis formation, expert opinion and commentaries are all considered for publication. The manuscript management system is completely online and includes a very quick and fair peer-review system, which is all easy to use. Visit http://www.dovepress.com/testimonials.php to read real quotes from published authors. 